\title{
Evidence for an arginine-specific mono(ADP- ribosyl)transferase in dormant spores of the fungus Phycomyces blakesleeanus
}

\author{
Martha Deveze-Alvarez, Jesús García-Soto and \\ Guadalupe Martinez-Cadena \\ Author for correspondence: Guadalupe Martinez-Cadena. Tel: +52 473 24996. Fax: +52 47324302. \\ e-mail: margua@quijote.ugto.mx
}

Instituto de Investigación en Biología Experimental, Facultad de Química,

Universidad de Guanajuato, Apdo. postal 187,

Guanajuato, Gto., 36000

Mexico

\begin{abstract}
A soluble mono(ADP-ribosyl)transferase was detected in dormant spores of Phycomyces blakesleeanus. Soluble proteins incubated with [ ${ }^{32}$ P]NAD revealed, after two-dimensional electrophoresis, three major ADP-ribosylated substrates with molecular masses of 38,37 and $36 \mathrm{kDa}$ and pl values of 6.9, 8.1 and 4.6, respectively. When these endogenous substrates were first ADP-ribosylated with [ $\left.{ }^{32} \mathrm{P}\right]$ NAD and then incubated for different times with either $3 \mathrm{M}$ hydroxylamine (pH 7.0) or $1 \mathrm{mM} \mathrm{HgCl}{ }_{2}$, only hydroxylamine released the incorporated radioactivity after $\mathbf{3 0}$ min incubation. Additionally, agmatine was used as a substrate for this enzyme. These data suggest that the mono(ADPribosyl)transferase is an arginine-specific enzyme. This enzymic activity was stimulated by $10 \mathrm{mM} \mathrm{MgCl}$ and by $250 \mu \mathrm{M}$ of the nitric-oxide-releasing agent sodium nitroprusside, and inhibited by $8 \mathrm{mM}$ benzamide, $0.4 \mathrm{mM} \mathrm{m}$ iodobenzylguanidine and $0.5 \mathrm{mM}$ novobiocin. The three ADP-ribosylation inhibitors affected the germination of $P$. blakesleeanus spores, leaving them as swollen cells. The effect of $\mathrm{MgCl}_{2}$, GTP and ATP on the ADP-ribosylation of the endogenous proteins was studied. The presence of two additional [ ${ }^{32}$ P]ADPribosylated proteins of 57 and $55 \mathrm{kDa}$ was observed in the absence of $\mathrm{MgCl}_{2}$. An increase in incorporation of radioactivity into the $55 \mathrm{kDa}$ band was observed when the assay was performed in the presence of GTP or ATP. The addition of $\mathrm{Mg}^{2+}$ together with either or both nucleotides eliminated the appearance of the 57 and $55 \mathrm{kDa}$ bands, but intensified the $37 \mathrm{kDa}$ band. Photoaffinity-labelling of the soluble fraction with $\left[\alpha-{ }_{-3}^{32} P\right]$ GTP revealed a $55 \mathrm{kDa}$ band together with other proteins of 32 and $17 \mathrm{kDa}$. These results suggest that among the five different endogenous substrates for the fungal mono(ADPribosyl)transferase, the $55 \mathrm{kDa}$ protein may be a GTP-binding protein.
\end{abstract}

Keywords: ADP-ribosyltransferase, Pbycomyces blakesleeanus, GTP-binding protein, dormant spores

\section{INTRODUCTION}

Mono-ADP-ribosylation is a post-translational modification of proteins by the enzymic transfer of ADP-ribose from NAD, resulting in alteration of the functional properties of the respective proteins. Mono(ADPribosyl)transferases have been identified in a range of eukaryotic cells and tissues. They have been purified from turkey red blood cells, hen and frog liver, and rabbit skeletal muscle. All of these enzymes catalyse the transfer

Abbreviations: MIBG, $m$-iodobenzylguanidine; NO, nitric oxide. of ADP-ribose from NAD to arginine (Williamson \& Moss, 1990). Also, a cysteine-specific ADP-ribosyltransferase has been purified from human erythrocytes (Jacobson et al., 1990).

ADP-ribosylation is a reversible modification cycle of proteins, since ADP-ribosylarginine and ADP-ribosylcysteine hydrolases have been identified in animal tissues in which the respective transferases have been detected (Moss et al., 1985; Williamson \& Moss, 1990). The role of mono-ADP ribosylation in eukaryotes is less well characterized than in prokaryotes, although it has been suggested by different authors that this modification could 
participate in a number of biological processes, for example stimulation of adenylyl cyclase activity, inhibition of $\mathrm{Na}^{+}$-dependent phosphate transport, increase in light sensitivity of salamander retinal rods, modulation of starvation and stress responses in cultured cells, regulation of $\mathrm{Ca}^{2+}$ release, inhibition of $\mathrm{Ca}^{2+}$-dependent ATPase activity, and alteration in protein phosphorylation (reviewed by Williamson \& Moss, 1990). It has been demonstrated that endogenous ADP-ribosylation is under the regulatory control of hormones and second messengers (Brüne \& Lapetina, 1989; Molina y Vedia et al., 1989; Brüne et al., 1990). Therefore, these findings suggest a possible role of ADP-ribosylation in the signaltransduction pathways mediated by an agonist-receptor system. On the other hand, it has been reported that a brefeldin A-sensitive mono(ADP-ribosyl)transferase might be involved in membrane traffic (De Matteis $e t$ al., 1994).

Phycomyces blakesleeanus is a zygomycete fungus whose spores show an endogenous dormancy, that is, they need an activation treatment to induce germination. The germination process involves a morphological transition from an elliptical spore to a spherical cell, with subsequent tube formation and development into mycelial cells in a suitable culture medium. Immediately after the activation treatment, the cytoplasmic cAMP levels are transiently elevated, suggesting that this second messenger might be the trigger of spore germination (for a review, see Van Laere et al., 1987). Mutants that do not germinate show no increase in cAMP (Van Laere \& Rivero, 1986; Rivero \& Cerdá-Olmedo, 1987), strongly supporting the hypothesis that this nucleotide is a critical agent in breaking $P$. blakesleeanus spore dormancy. Other rapid metabolic changes include an increase in the concentration of fructose 2,6-bisphosphate, and in the enzymic activities of trehalase and glycerol-3-phosphatase. These enzymic activities are regulated by phosphorylation, probably through a cAMP-dependent protein kinase (Van Laere \& Hendrix, 1983; Van Mulders \& Van Laere, 1984; Van Laere et al., 1987).

We are interested in the elucidation of the biochemical events underlying spore germination in P. blakesleeanus. The purpose of this study was to characterize endogenous ADP-ribosylation in dormant spores in an attempt to identify substrate proteins in the fungus.

\section{METHODS}

Strain. The wild-type strain of P. blakesleeanus NRRL 1555 (-) (Northern Regional Research Laboratory, USDA, Peoria, IL, USA) was used throughout this work.

Media and growth conditions. The fungus strain was maintained and propagated in YPG medium (Bartnicki-Garcia \& Nickerson, 1962). Sporangiospores were produced on YPG solidified with $2 \%(\mathrm{w} / \mathrm{v})$ agar from cultures incubated at $24{ }^{\circ} \mathrm{C}$ for $6 \mathrm{~d}$ under diffused light.

To promote germination and growth, the spores were activated chemically by including ammonium acetate to a final concentration of $30 \mathrm{mM}$ in Sutter medium composed of glucose and asparagine (Sutter, 1975). Benzamide, $m$-iodobenzylguanidine
(MIBG) or novobiocin were added to different culture flasks at the concentrations indicated in Results before spore inoculation. Germination was determined after $20 \mathrm{~h}$ growth and expressed as the percentage of cells exhibiting a germ tube ( 200 cells were counted).

Preparation of cell-free extracts. Cell-free extracts from dormant spores were obtained basically as described by CarrilloRayas et al. (1988), with some modifications. Briefly, the spores were washed and resuspended in $50 \mathrm{mM}$ Tris/HCl buffer $(\mathrm{pH} 7 \cdot 0)$ containing $10 \%(\mathrm{v} / \mathrm{v})$ glycerol, $5 \mathrm{mM}$ EGTA, $5 \mathrm{mM}$ EDTA, and $5 \mu \mathrm{g}$ antipain $\mathrm{ml}^{-1}$. About $5 \mathrm{ml}\left(10^{10}\right.$ spores $)$ of the suspension was mixed with an equal volume of glass beads $(0.45-0.50 \mathrm{~mm}$ diam.) and broken in a Braun model MSK cell homogenizer for $180 \mathrm{~s}$ while cooling with a stream of $\mathrm{CO}_{2}$. The crude extract was centrifuged at $100000 \mathrm{~g}\left(r_{\text {av }}\right)$ for $60 \mathrm{~min}$ and the supernatant (cytosol) was divided into aliquots and kept at $-20^{\circ} \mathrm{C}$ until use.

Assay of ADP-ribosylation. ADP-ribosylation was carried out in a reaction mixture $(40 \mu \mathrm{l})$ composed of: $40 \mathrm{mM} \mathrm{MES}$ (pH 6.0), $1-10 \mu \mathrm{M}\left[{ }^{32} \mathrm{P}\right] \mathrm{NAD}(3.5 \mu \mathrm{Ci}$ per assay; $1 \mu \mathrm{Ci}=$ $37 \mathrm{kBq}$ ) and $75-100 \mu \mathrm{g}$ protein (as indicated in Results). When indicated, $10 \mathrm{mM} \mathrm{MgCl}_{2}, 10 \mathrm{mM} \mathrm{D}^{\prime} \mathrm{T}^{\prime} \mathrm{T}, 1 \mathrm{mM} \mathrm{A}^{\prime} \mathrm{TP}$ and $1 \mathrm{mM}$ GTP were added separately or combined. The reaction was terminated by adding $100 \mu \mathrm{l} 50 \%(\mathrm{w} / \mathrm{v})$ trichloroacetic acid (TCA). Precipitates were collected onto GF/B Whatman filters, washed, dried, and radioactivity was measured in a Beckman LS 7800 spectrophotometer. To visualize endogenous ADP-ribosylated proteins, assays were done as described above, but the reaction was terminated by the addition of SDS-PAGE solubilization buffer $(2 \times)$. Samples were boiled for 3 min and subjected to SDS-PAGE (10\%, w/v, acrylamide) (Laemmli, 1970). After electrophoresis the gels were stained with Coomassie blue, dried, and exposed (7-10 d) to X-OMAT films for autoradiography. For the two-dimensional gel electrophoresis, the reaction was terminated by the addition of lysis buffer (9.8 M urea, 2\% NonidetP-40, 2\% (v/v) ampholytes $\mathrm{pH} 7-9$, $100 \mathrm{mM}$ DTT) and separated by IEF-SDS-PAGE as described by Bravo (1984). When ADP-ribosyltransferase activity was assayed with $75 \mathrm{mM}$ agmatine as exogenous substrate, samples were diluted fivefold with water after 90 min incubation at $30{ }^{\circ} \mathrm{C} . \quad\left[{ }^{14} \mathrm{C}\right]$ ADP-ribosyl agmatine was separated from $\left[{ }^{14} \mathrm{C}\right] \mathrm{NAD}$ on a Partisil $10 \mathrm{SAX}$ column $(4.6 \times 250 \mathrm{~mm})$ used with a mobile phase of $25 \mathrm{mM}$ potassium phosphate buffer

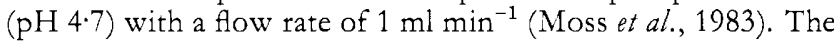
diluted fraction $(250 \mu \mathrm{l})$ was injected onto the HPLC column and fractions of $0.5 \mathrm{ml}$ were collected and radioactivity was measured as described above. Under these experimental conditions $\left[{ }^{14} \mathrm{C}\right] \mathrm{ADP}$-ribosylated agmatine and $\left[{ }^{14} \mathrm{C}\right] \mathrm{NAD}$ had retention times of $5 \mathrm{~min}$ and $8 \mathrm{~min}$, respectively.

$\left[\alpha^{32} \mathrm{P}\right]$ GTP photoaffinity-labelling of soluble proteins. This procedure was the same as that described by Martínez-Cadena et al. (1995).

Protein determination. Protein concentration was estimated by the Lowry method, using serum bovine albumin as standard.

\section{RESULTS AND DISCUSSION}

A soluble mono(ADP-ribosyl)transferase activity was detected in extracts of dormant spores of $P$. blakesleeanus. This enzymic activity increased linearly up to $200 \mu \mathrm{g}$ protein and 90 min incubation, after which no change of activity was observed. Additionally, this enzymic activity showed an optimum $\mathrm{pH}$ of $6 \cdot 5$, and used casein and albumin as substrates. The activity was lost after in- 


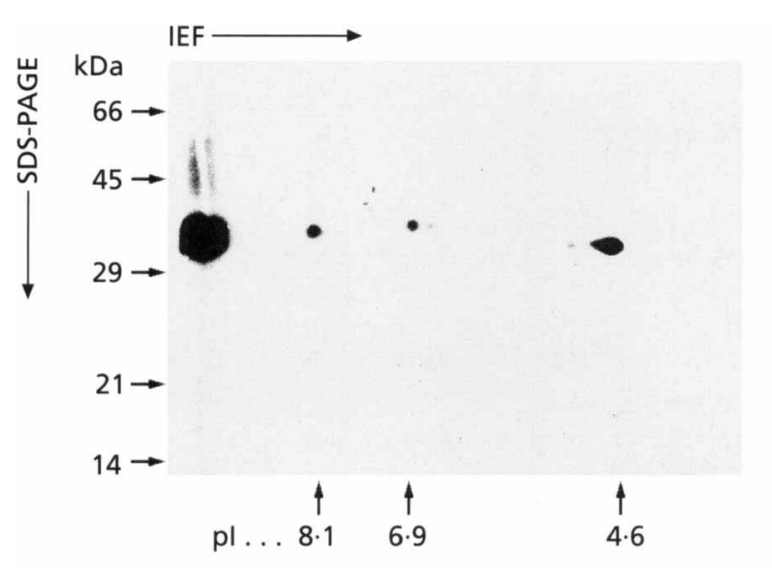

Fig. 1. Two dimensional electrophoresis of [ $\left.{ }^{32} \mathrm{P}\right] A D P-$ ribosylated soluble proteins from $P$. blakesleeanus. The cytosolic fraction (100 $\mu$ g protein) was incubated under ADP-ribosylation conditions as described in Methods. Proteins were separated by two-dimensional IEF-SDS-PAGE followed by autoradiography. The same results were observed in three other independent experiments.

cubation at $95^{\circ} \mathrm{C}$ for $5 \mathrm{~min}$, therefore discounting the addition of ADP-ribose adducts to the protein (data not shown). When the soluble extracts were investigated for the presence of endogenous substrates, a broad band with molecular mass of $\sim 37 \mathrm{kDa}$ was observed by SDSPAGE and autoradiography to be a very good substrate for this enzyme (Fig. 1). This modified protein was subjected to isoelectric focusing gel separation and three major bands of $38 / 6.9,37 / 8.1$ and $36 / 4.6 \mathrm{kDa} / \mathrm{pI}$ were observed (Fig. 1).

Meyer et al. (1988) have reported different chemical treatments which can determine the amino acid bound to the ADP-ribose; for example, hydroxylamine and $\mathrm{HgCl}_{2}$ have been used to determine arginine and cysteine modification, respectively. Thus, we used these chemical treatments to determine the amino acid modified by the Pbycomyces enzyme. Fig. 2 shows that no significant decrease in radioactivity was observed in the presence of $1 \mathrm{mM} \mathrm{HgCl}_{2}$. The radioactivity was partially released from the endogenous $\left[{ }^{32} \mathrm{P}\right]$ ADP-ribosylated substrates after $30 \mathrm{~min}$ and totally after $60 \mathrm{~min}$ of incubation in the presence of $3 \mathrm{M}$ hydroxylamine $(\mathrm{pH} \mathrm{7} \cdot 0)$. It has been reported that the polymers of ADP-ribose (ADP-riboseglutamate) are hydroxylamine-labile and totally released after a short period $(10 \mathrm{~min})$ of incubation with $3 \mathrm{M}$ hydroxylamine ( $\mathrm{pH} 7 \cdot 0$ ) (Riquelme et al., 1979). Our data with the hydroxylamine treatment eliminate the possibility of a poly(ADP-ribosyl)synthetase under our experimental conditions. Additionally, this mono(ADPribosyl)transferase used as an ADP-ribose acceptor a compound containing a guanidino moiety such as agmatine (data not shown). Smets et al. (1990) have reported that MIBG is a high-affinity substrate for the mono(ADP-ribosyl)transferase of turkey erythrocyte membranes and of cholera toxin. Under our experimental conditions, the fungal transferase did not use

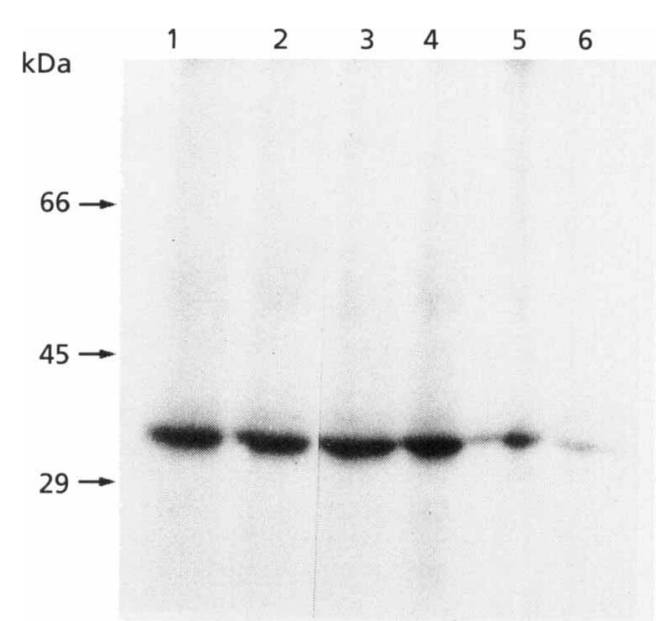

Fig. 2. Analysis of the ADP-ribose amino acid acceptor. The cytosolic fraction (100 $\mathrm{g}$ protein) from P. blakesleeanus was incubated under ADP-ribosylation conditions. After $1 \mathrm{~h}$ at $30^{\circ} \mathrm{C}$ samples were heated at $95^{\circ} \mathrm{C}$ for $3 \mathrm{~min}$ and divided into three aliquots. Where indicated, $3 \mathrm{M}$ hydroxylamine $(\mathrm{pH} 7)$ or $1 \mathrm{mM}$ $\mathrm{HgCl}_{2}$ was added. Samples were withdrawn after 30 and $60 \mathrm{~min}$ incubation and [ ${ }^{32} \mathrm{P}$ ]ADP-ribosylated proteins were separated by $10 \%$ SDS-PAGE followed by autoradiography. Lanes: 1 , control $30 \mathrm{~min}$; 2, control $60 \mathrm{~min} ; 3, \mathrm{HgCl}_{2} 30 \mathrm{~min} ; 4, \mathrm{HgCl}_{2} 60 \mathrm{~min}$; $3 \mathrm{M}$ hydroxylamine $30 \mathrm{~min}$; and 6 , hydroxylamine $60 \mathrm{~min}$. The same results were obtained in three other independent experiments.

$10 \mathrm{mM}$ MIBG as a substrate. These results indicate that the enzyme is an NAD:arginine-specific (ADPribosyl)transferase.

\section{Biochemical characteristics of the ADP- ribosyltransferase}

It has been reported that $\mathrm{Mg}^{2+}$ stimulates the enzymic activity of ADP-ribosyltransferases detected in different types of cells (Soman et al., 1984). We investigated the ADP-ribosylation of endogenous proteins in the absence or presence of $\mathrm{MgCl}_{2}$ alone or in combination with GTP or ATP. Fig. 3(a) shows the presence of two additional $\left[{ }^{32} \mathrm{P}\right]$ ADP-ribosylated proteins, a predominant and a minor band with molecular masses of 55 and $57 \mathrm{kDa}$, respectively, when the assay was performed in the absence of $\mathrm{Mg}^{2+}$. An increase in incorporation of radioactivity into the $57 \mathrm{kDa}$ band was observed when the enzymic assays were performed in the presence of GTP or ATP. The addition of $\mathrm{Mg}^{2+}$ together with either or both nucleotides eliminated the ADP-ribosylation of the 57 and $55 \mathrm{kDa}$ bands, but intensified the radiolabelling in the $37 \mathrm{kDa}$ band. When casein was used as a substrate for ADP-ribosylation, it was observed that $\mathrm{MgCl}_{2}$ and GTP added independently stimulated the $\left[{ }^{32} \mathrm{P}\right] A D P-r i b o s e$ incorporation, whereas ATP caused inhibition of the enzymic activity (data not shown).

In mycelia of Neurospora crassa, Hasunuma (1991) reported at least seven different guanine-nucleotide-binding proteins which were endogenously ADP-ribosylated. There- 
(a)

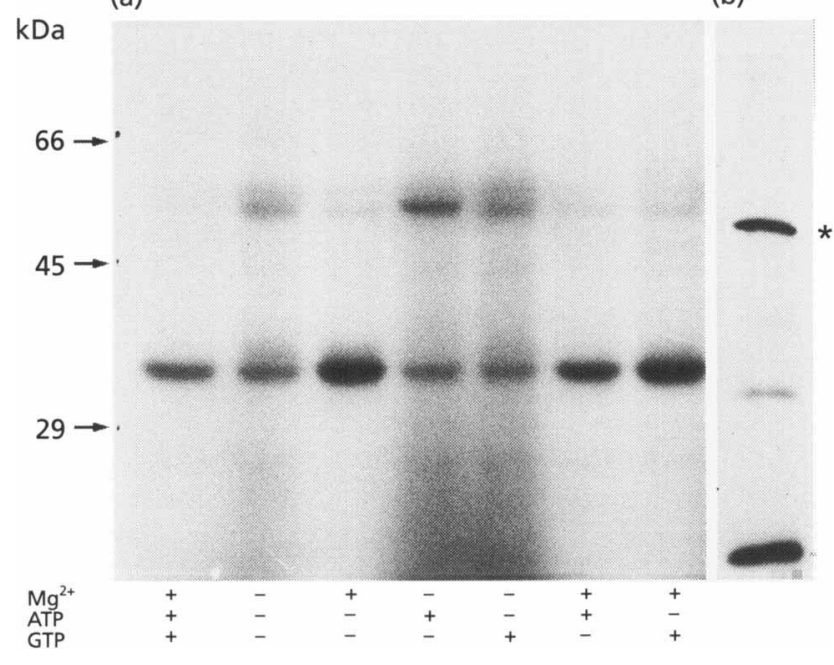

Fig. 3. Endogenous ADP-ribosylation and photoaffinitylabelling by $\left[\alpha-{ }^{32}\right.$ P]GTP of soluble proteins. (a) The cytosolic fraction $(100 \mu \mathrm{g}$ protein) of $P$. blakes/eeanus was incubated under ADP-ribosylation conditions and $10 \mathrm{mM} \mathrm{MgCl}_{2}, 1 \mathrm{mM}$ GTP or/and $10 \mathrm{mMATP}$ were added as indicated. (b) Photoaffinity-labelling was assayed by irradiating the soluble proteins $(100 \mu \mathrm{g})$ with UV light for $10 \mathrm{~min}$ in the presence of $[\alpha-$ ${ }^{32}$ P]GTP. In both (a) and (b), proteins were then separated by $10 \%$ SDS-PAGE followed by autoradiography. The position of the $55 \mathrm{kDa}$ protein (see text) is marked by an asterisk. The same results were obtained in three other independent experiments.

fore, the cytosolic fraction was incubated with $\left[\alpha_{-}{ }^{32} \mathrm{P}\right] \mathrm{GTP}$ and the presence of GTP-binding proteins was detected by photoaffinity labelling as described in Methods. Fig. 3 (b) shows that three major bands with molecular masses of 55,32 , and $17 \mathrm{kDa}$ bound $\left[\alpha-{ }^{32} \mathrm{P}\right] \mathrm{GTP}$; these results suggest that the $55 \mathrm{kDa}$ protein which is a substrate for the (ADP-ribosyl)transferase may be a GTP-binding protein.

Sodium nitroprusside (Brüne \& Lapetina, 1989) and benzamide (Tanigawa et al., 1984; Banasik et al., 1992) have been described as positive and negative effectors of ADP-ribosylation, respectively. When the effect of these compounds on the enzymic activity was tested in the presence of $\mathrm{MgCl}_{2}, 0.1 \mathrm{mM}$ sodium nitroprusside enhanced the activity by a factor of $1 \cdot 23$, whereas $4 \mathrm{mM}$ benzamide inhibited activity by almost $50 \%$ (data not shown). These results agree with those observed for other ADP-ribosyl transferases (Tanigawa et al., 1984).

Furthermore, we investigated the effect of sodium nitroprusside, which is a NO-releasing agent, and benzamide on the $\left[{ }^{32} \mathrm{P}\right] A D P$-ribosylation of the $37 \mathrm{kDa}$ protein; the cytosolic proteins were incubated under ADP-ribosylation conditions in the presence of different concentrations of these compounds. Fig. 4(a) shows that the intensity of the labelled band increased with the sodium nitroprusside concentration and decreased when the benzamide concentration was increased. Densitometric analysis of the radiolabelled bands revealed a $300 \%$ stimulation with $250 \mu \mathrm{M}$ sodium nitroprusside and a $50 \%$ (a)

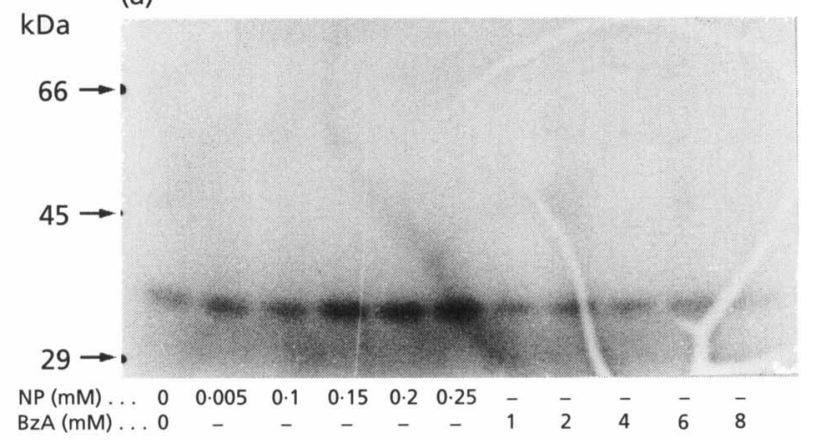

(b)

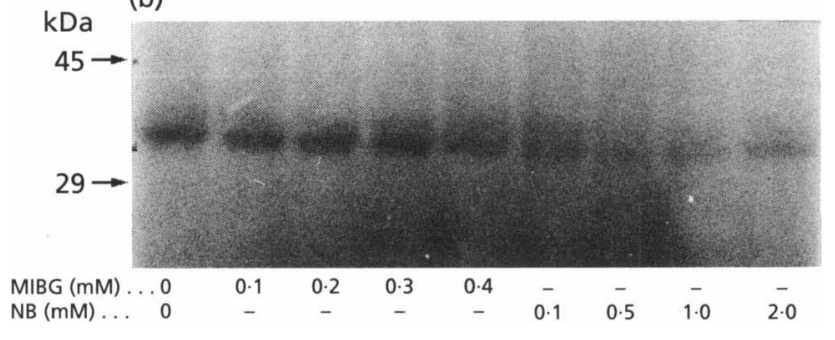

Fig. 4. Effect of nitroprusside, benzamide, MIBG and novobiocin on $P$. blakesleeanus ADP-ribosyltransferase activity. (a) The cytosolic fraction (100 $\mu \mathrm{g}$ protein) was incubated under ADP-ribosylation conditions and, where indicated, different concentrations of sodium nitroprusside (NP) or benzamide (BzA) were added to the reaction mixture. (b) The cytosolic fraction (100 $\mu \mathrm{g}$ protein) was incubated under ADP-ribosylation conditions and, where indicated, different concentrations of MIBG or novobiocin (NB) were added to the reaction mixture. After $1 \mathrm{~h}$ incubation proteins were separated by $10 \%$ SDS-PAGE followed by autoradiography. The same results were obtained in two other independent experiments.

inhibition with $8 \mathrm{mM}$ benzamide. A NO-dependent endogenous cysteine-specific ADP-ribosylation of a $41 \mathrm{kDa}$ protein has been reported in Dictyostelium discoideum (Tao et al., 1992). McDonald \& Moss (1993) reported that the NO-releasing agent sodium nitroprusside produces the covalent binding of NAD through non-enzymic $S$ nitrosylation of cysteine residues in those proteins where stimulation occurred. We observed that heated $\left(95^{\circ} \mathrm{C}\right.$, $3 \mathrm{~min}$ ) soluble extracts incubated in either the absence or the presence of $200 \mu \mathrm{M}$ sodium nitroprusside failed to show detectable NAD incorporation into the $37 \mathrm{kDa}$ protein (data not shown). These observations eliminate the possibility of non-enzymic addition of NAD adducts in P. blakesleeanus protein. Banasik et al. (1992) reported an $\mathrm{IC}_{50}$ value of $4.5 \mathrm{mM}$ for the effect of benzamide on the mono(ADP-ribosyl)transferase from hen heterophils, which agrees with our data on inhibition of the fungal enzyme.

Also, the effect of two other strong mono-ADP-ribosylation inhibitors, MIBG and novobiocin, was studied. Fig. 4(b) shows that the intensity of ADP-ribosylation of the $37 \mathrm{kDa}$ band was decreased by incubation of the extracts with either MIBG or novobiocin; densitometric analysis of the bands indicated a $25 \%$ inhibition with 


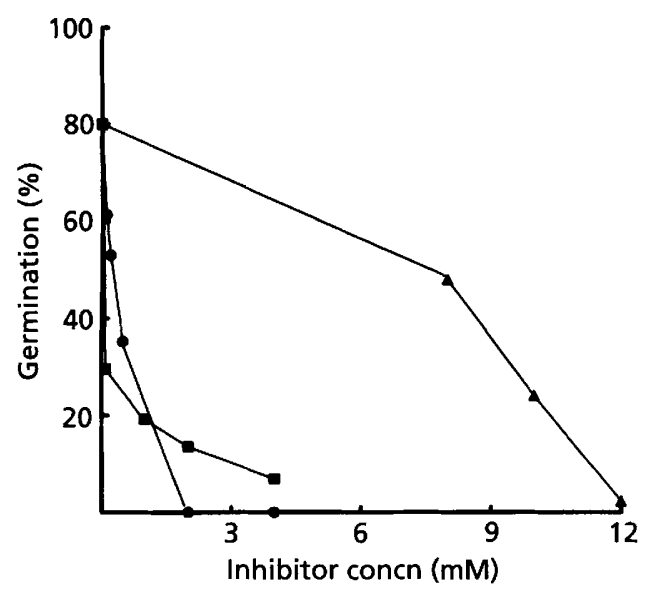

Fig. 5. Effect of different inhibitors on the germination of $P$. blakesleeanus spores. Spores $\left(5 \times 10^{5} \mathrm{ml}^{-1}\right)$ were inoculated in flasks containing liquid Sutter medium (Sutter, 1975), $30 \mathrm{mM}$ ammonium acetate and different concentrations of benzamide (A). MIBG (O) or novobiocin ( $\square$ ). After $20 \mathrm{~h}$ growth, germination was followed microscopically. Two hundred cells were counted. Similar results were obtained in three different experiments.

$0.4 \mathrm{mM}$ MIBG and a $36 \%$ inhibition with $0.5 \mathrm{mM}$ novobiocin (data not shown). These data are somewhat higher than those reported for the mono(ADP-ribosyl)transferase activity (IC $\mathrm{IC}_{50} 0.1 \mathrm{mM}$ for MIBG and $0.28 \mathrm{mM}$ for novobiocin) from turkey erythrocyte membranes (Smets et al., 1990; Banasik et al., 1992).

Since we observed an inhibitory effect on the ADP(ribosyl)transferase activity of spore extracts, we investigated the effect of these drugs on the germination process of $P$. blakesleeanus. Fig. 5 shows that the concentrations necessary to inhibit $50 \%$ of the spore germination were $0.05 \mathrm{mM}, 0.2 \mathrm{mM}$ and $8 \mathrm{mM}$ for novobiocin, MIBG and benzamide, respectively. All the above inhibitors stopped the germination process, preventing germ tube protrusion and leaving the spores as swollen cells. These data suggest that ADP-ribosylation may be involved in the germination process of $P$. blakesleeanus, particularly in germtube formation.

The results presented in this work indicate the presence of a soluble NAD : arginine ADP-ribosyltransferase in dormant spores of $P$. blakesleeanus which could be involved in the germination of the spores, particularly in germ-tube extrusion, and of five major soluble endogenous substrates, of $57,55,38,37$ and $36 \mathrm{kDa}$. They also suggest that the $55 \mathrm{kDa}$ protein could be a $\mathrm{G}$ protein. Work is in progress to identify the nature of these proteins.

\section{ACKNOWLEDGEMENTS}

M.A.D.A. is a predoctoral student with a scholarship from CONACyT. This work was supported by the Consejo Nacional de Ciencia y Tecnología of México (grants N305 and N3032) and the Third World Academy of Sciences (grant BC90-111). We gratefully thank Dr J. Félix Gutiérrez-Corona for critical reading of the manuscript.

\section{REFERENCES}

Banasik, M., Komura, H., Shimoyama, M. \& Ueda, K. (1992). Specific inhibitors of poly(ADP-ribose) synthetase and mono(ADPribosyl)transferase. J Biol Chem 267, 1569-1575.

Bartnicki-Garcia, S. \& Nickerson, W. J. (1962). Nutrition, growth, and morphogenesis of Mucor rouxii. J Bacteriol 84, 841-858.

Bravo, R. (1984). Two dimensional gel electrophoresis : a guide for the beginner. In Two-dimensional Gel Electrophoresis of Proteins, pp. 3-36. Edited by J. E. Celis \& R. Bravo. New York: Academic Press.

Brune, B. \& Lapetina, E. G. (1989). Activation of cytosolic ADPribosyltransferase by nitric oxide-generating agents. $J$ Biol Chem 264, 8455-8458.

Brune, B., Molina y Vedia, L. \& Lapetina, E. G. (1990). Agonist induced ADP-ribosylation of a cytosolic protein in human platelets. Proc Natl Acad Sci US A 87, 3304-3308.

Carrillo-Rayas, M. T., Garcĺa-Soto, J. \& Martínez-Cadena, G. (1988). 12-O-Tetradecanoyl phorbol-13-acetate interferes with germination of Pbycomyces blakesleeanus sporangiospores. FEBS Lett 238, 441-444.

De Matteis, M. A., DiGirolamo, M., Colanzi, A., Pallas, M., DiTullio, G., McDonald, L. S., Moss, J., Santini, G., Bannykh, S., Corda, D. \& Luini, A. (1994). Stimulation of endogenous ADPribosylation by brefeldin A. Proc Natl Acad Sci US A 91, 1114-1118.

Hasunuma, K. (1991). Nucleoside triphosphate (NTP)-binding proteins and endogenous ADP-ribosyl transferase in Neurospora crassa. Plant Cell Pbysiol 32, 653-664.

Jacobson, M. K., Loflin, P. T., Aboul-Ela, N., Minmuang, M., Moss, J. \& Jacobson, E. L. (1990). Modification of plasma membrane protein cysteine residues by ADP-ribose in vivo. $J$ Biol Chem $\mathbf{2 6 5}$, 10825-10828.

Laemmli, U. K. (1970). Cleavage of structural proteins during the assembly of the head of bacteriophage T4. Nature 227, 680-685.

McDonald, L. J. \& Moss, J. (1993). Nitric oxide-independent, thiolassociated ADP-ribosylation inactivates aldehyde dehydrogenase. $J$ Biol Chem 268, 17878-17882.

Martínez-Cadena, G., Novoa-Martínez, G., González-Hernández, A. \& Garcla-Soto, J. (1995). The GTP-binding protein $G \alpha_{\mathrm{s}}$ is present in dormant spores and expressed differentially during spore germination of the fungus Pbycomyces blakesleeanus. Microbiology 141, 3149-3154.

Meyer, T., Koch, R., Fanick, W. \& Hilz, H. (1988). ADP-ribosyl proteins formed by pertussis toxin are specifically cleaved by mercury ions. Biol Chem Hoppe-Seyler 369, 579-583.

Molina y Vedia, L., Nolan, R. D. \& Lapetina, E. G. (1989). The effect of iloprost on the ADP-ribosylation of Gs $\alpha$ (the $\alpha$-subunit of Gs). Biochem J 261, 841-845.

Moss, J., Yost, A. \& Stanley, S. J. (1983). Amino acid-specific ADPribosylation. J Biol Chem 258, 6466-6470.

Moss, J., Jacobson, M. K. \& Stanley, S. J. (1985). Reversibility of arginine-specific mono(ADP-ribosylation): identification in erythrocytes of an ADP-ribose-L-arginine cleavage enzyme. Proc Natl Acad Sci US A 82, 5603-5607.

Riquelme, P. T., Burzio, L. O. \& Koide, S.S. (1979). ADPribosylation of rat liver lysine-rich histone in vitro. $J$ Biol Chem 254, 3018-3028.

Rivero, F. \& Cerdá-Olmedo, E. (1987). Spore activation by acetate, propionate and heat in Pbycomyces mutants. Mol Gen Genet 209, 149-153.

Smets, L. A., Loesberg, C., Janssen, M. \& Van Rooij, H. (1990). Intracellular inhibition of mono(ADP-ribosylation) by meta-iodo- 
benzylguanidine: specificity, intracellular concentration and effects on glucocorticoid-mediated cell lysis. Biocbim Biophys Acta 1054, 49-55.

Soman, G., Mickelson, S. J., Louis, C. F. \& Graves, D. J. (1984). NAD:guanidino group specific mono ADP-ribosyltransferase activity in skeletal muscle. Biochem Biopbys Res Commun 120, 973-980.

Sutter, R. P. (1975). Mutations affecting sexual development in Pbycomyces blakesleeanus. Proc Natl Acad Sci US A 72, 127-130.

Tanigawa, Y., Tsuchiya, M., Imai, Y. \& Shimoyama, M. (1984). ADP-ribosyltransferase from hen liver nuclei. $J$ Biol Chem 259, 2022-2029.

Tao, Y., Howlett, A. \& Klein, C. (1992). Nitric oxide stimulates the ADP-ribosylation of a $41-\mathrm{kDa}$ cytosolic protein in Dictyostelium discoideum. Proc Natl Acad Sci US A 89, 5902-5906.

Van Laere, A. J. \& Hendrix, P. (1983). Cyclic AMP-dependent in vitro activation of trehalase from dormant Phycomyces blakesleeanus spores. J Gen Microbiol 129, 3287-3290.
Van Laere, A. J. \& Rivero, F. (1986). Properties of a germination mutant of Pbycomyces blakesleeanus. Arch Microbiol 145, 290-294.

Van Laere, A. J., Van Assche, J. A. \& Furch, B. (1987). The sporangiospore: dormancy and germination. In Pbycomyces, pp. 247-279. Edited by E. Cerdá-Olmedo \& E. D. Lipson. Cold Spring Harbor, NY: Cold Spring Harbor Laboratory.

Van Mulders, R. M. \& Van Laere, A. J. (1984). Cyclic AMP, trehalase and germination of Phycomyces blakesleeanus spores. $J$ Gen Microbiol 130, 541-547.

Williamson, K. C. \& Moss, J. (1990). Mono-ADP-ribosyltransferases and ADP-ribosylarginine hydrolases: a mono-ADP ribosylation cycle in animal cells. In $A D P$-ribosylating Toxins and $G$ Proteins: Insights into Signal Transduction, pp. 493-510. Edited by J. Moss \& M. Vaughan. Washington, DC: American Society for Microbiology.

Received 22 February 1996; revised 12 May 1996; accepted 12 June 1996. 